\title{
Scandinavian Sympathies and Nordic Unity: The Rhetoric of Scandinavianness in the Nineteenth Century
}

The history of "Nordic" and - in particular - "Scandinavian" as flexible and contested concepts may be traced back at least to the early nineteenth century. This history is strongly connected with competing national and pan-national projects within the Nordic region. This chapter seeks to explore the emergence and transformation of "Scandinavian" and the related and more widespread term "Nordic" as appealing and contested rhetorical concepts during the long nineteenth century. The pan-Scandinavian movement, it will be argued, played a key role in this development by stimulating a widespread rhetoric of "Nordicness" - or rather of "Scandinavianness" - in the 1840s, thus adding significant dimensions of meanings to these concepts. ${ }^{1}$

With the introduction of a range of new phrases with rhetorical power, such as "Scandinavian sympathies" and the "Scandinavian idea," the usage of the term "Scandinavian" rose rapidly from the mid-nineteenth century onwards. An emergent public sphere and print culture, increasingly influenced by what was to be known as "Scandinavianism," stimulated this tendency. Civil society initiatives further contributed to the development. A range of new pan-Scandinavian associations that termed themselves "Scandinavian" and later "Nordic" was established within as well as beyond the Scandinavian region. ${ }^{2}$

In mapping the usage of these terms, a combination of quantitative and qualitative analysis, of distant and close readings is employed. Distant readings of Nordic newspaper corpora, from Norway, Sweden, Denmark and Finland respectively, ${ }^{3}$ gives a reasonable idea of key word frequencies and collocational re-

1 There are examples, although scarce, of the use of the terms "Nordicness" (Nordiskhed) and "Scandinavianness" (Skandinaviskhed) from the mid-1840s.

2 Ruth Hemstad, "Organizational Scandinavianism Abroad: Literature, Sociability and PanScandinavian Associational Life in German-speaking Europe 1842-1912," in Mit dem Buch in der Hand: Beiträge zur deutsch-skandinavischen Buch- und Bibliotheksgeschichte/A Book in Hand: German-Scandinavian Book and Library History, ed. Marie-Theres Federhofer and Sabine Meyer, Berliner Beiträge zur Skandinavistik 31 (Berlin: Norderopa-Institut, 2021), 159-183; Ruth Hemstad, Fra Indian summer til nordisk vinter: Skandinavisk samarbeid, skandinavisme og unionsoppløsningen (Oslo: Akademisk Publisering, 2008).

3 The following Nordic newspaper databases are used in this study: Nasjonalbiblioteket, Norway, www.nb.no; Mediastream, Denmark, www2.statsbiblioteket.dk; Svenska Dagstidningar,

Ә OpenAccess. (c) 2022 Ruth Hemstad, published by De Gruyter. (cc))BY This work is licensed under the Creative Commons Attribution 4.0 International License. https://doi.org/10.1515/9783110730104-003 
lationships - words that are frequently used in combination with the key words. By comparing the frequency of the terms "Nordic" and "Scandinavian" in newspapers in the Nordic countries during the nineteenth century (1790-1900), made possible through the significant amount of digitized material available, some interesting patterns appear. Although the analysis will seek to identify and explore changes throughout the century, some periods will be of particular interest.

The emergence of a specific pan-Scandinavian vocabulary and the rhetorical use of certain phrases based on the adjectives "Scandinavian" and "Nordic" is evident from the mid-1840s. In order to understand the contested character of these notions, which is particularly apparent in parts of the Norwegian national discourse, it is, however, necessary to examine the conceptual transformations of the previous period, especially since 1814. In the 1840s there was an interesting shift not only in the frequency but also - as close reading reveals - in the meaning of the terms "Scandinavia" and "Scandinavian". Following the 1840s, pan-Scandinavian rhetoric had a lasting influence and around 1900, a renewed rhetoric of Scandinavianness emerged followed by a rejection of related concepts in parts of the Swedish public sphere. ${ }^{4}$

In addition to mapping the frequency during the century through key word searches, collocate searching is employed in order to identify and map relevant phrases. ${ }^{5}$ Certain phrases are significant and were extensively used, especially in the period between the 1840s and the 1860s - including "Scandinavian sympathies." Close readings of additional relevant sources, such as pamphlets, books, journal and newspaper articles, are used to analyse and place the main results in their relevant discursive and political contexts.

A first main point is that the term "Nordic" is older and more frequently used than "Scandinavian" until the first decades of the nineteenth century. ${ }^{6}$ Key word searches of the digital newspaper corpora in the Scandinavian national libraries show that "Nordic" is used throughout the eighteenth century. ${ }^{7}$ There are only

Sweden, tidningar.kb.se; DIGI-Nationalbibliotekets digitala samlingar, Finland, digi.kansalliskirjasto.fi.

4 Hemstad, Fra Indian summer, 297-359.

5 Collocate searching was applied on the text corpus at the National Library of Norway in cooperation with Lars G. Johnsen at the Norwegian Language Bank at the National Library.

6 In the Nordic newspaper databases, the oldest reference to "Scandinavian" is in a Danish newspaper in 1781. Full text searches for "skandinavisk" and "scandinavisk" in the comprehensive Norwegian book corpus at the National Library of Norway and searches for the same words in titles in the national library catalogues in Norway, Sweden, and Denmark, support this result.

7 The use of "Nordic" and "Norden" in the eighteenth century often reflected a wide concept of the North that included Russia, Poland and Prussia. Henriette Kliemann-Geisinger, "Mapping 
few examples, however, of "Scandinavian" from the last part of the century. Several of them refer to the association Skandinavisk Literatur-Selskab (Scandinavian literary society), established 1796, and its journal Skandinavisk Museum. ${ }^{8}$ The society aimed at promoting literary connections between the "Scandinavian realms" by facilitating closer contacts between Danish and Swedish intellectuals and improving knowledge of "Scandinavian literature" - a new phrase at this time.

"Scandinavia" was originally a Latin term, derived from "Scania" in the south-eastern part of Sweden. Early examples from the mid and late eighteenth century point towards a growing awareness of Scandinavia as a potential cultural-political entity consisting of Denmark, Norway, and Sweden. ${ }^{9}$ The use of the term also reflected the renewed interest in Old Norse culture at the time. "Scandinavia" and "the old Scandinavians" were terms used to describe the area and its inhabitants in the ancient era. These terms did not stem from Saga literature but from Greek and Roman sources, an aspect frequently pointed out by nationally-minded Norwegian scholars arguing against the unhistorical and "false" use of these terms by Danish and Swedish scholars. ${ }^{10}$

Norwegian newspapers and journals in the 1820s and 1830s regularly stated that "Scandinavian," "Scandinavians," and "Scandinavia" were recent terms. "A Scandinavian is a fresh new word," the newspaper Morgenbladet stated in 1829. ${ }^{11}$ In 1835, it was commented that "Scandinavia" had recently became popular - in Denmark as a common name for the three Nordic countries, and in Sweden as a common name for Norway and Sweden. ${ }^{12}$ Two years later, during a period of increased political tension between the two union partners Norway and Sweden,

the North - Spatial Dimensions and Geographical Concepts of Northern Europe," in Northbound: Travels, Encounters, and Constructions 1700-1830, ed. Karen Klitgaard Povlsen (Aarhus: Aarhus University Press, 2007), 70 - 76.

8 Skandinavisk Museum (1798-1803), followed by the book series Det Skandinaviske Literaturselskabs Skrifter (1805-1832).

9 Erik Bodensten, "Scandinavia Magna: En alternativ nordisk statsbildning 1743," in Nordens historiker: Vänbok till Harald Gustafsson, ed. Erik Bodensten et al. (Lund: Historiska Institutionen, Lunds Universitet, 2018), 61-75; Frederik Sneedorf, "Vigtigheden af de tre nordiske Rigers Forening. En Tale af afgangne Professor F. Sneedorf, holden i det nordiske Selskab i London i Foraaret 1792," Skandinavisk Museum 2 (1798): 122-134.

10 Historians such as Peter Andreas Munch and Jens Christian Berg presented this sort of argument. See Ruth Hemstad, “'Norden' og 'Skandinavien.' Begrepsbruk i brytningstid,” in Nordens historiker, ed. Erik Bodensten et al., 45-60.

11 "En Skandinaver er et nybagt Ord," published as part of the poem "Forsvar for Rævbælgmakeren” (anon.) in Morgenbladet, 28 August 1829, reprinted in Tillæg til Morgenbladet, 9 April 1833. 12 "Norge," Morgenbladet, 10 January 1835. The article reprints parts of an article by Jens Christian Berg published in the series Samlinger til det norske Folks Sprog og Historie. 
another Norwegian newspaper criticized the widespread Swedish usage of such "disgusting" terms as "Scandinavia," "Scandinavians," and "Scandinavian" in books and maps. ${ }^{13}$ In 1839, another writer argued against Danish utilization of "the blurred and ambiguous terms 'Nordic' [...] and the later invented favourite expressions 'Scandinavians,' Scandinavian" as common denominators for the three Nordic nations by those "who want to appropriate what belongs to Norwegian history only," hinting at Danish efforts of appropriation of Old Norse heritage. $^{14}$

The Norwegian wariness towards the use of the adjective "Scandinavian" and the related terms "Scandinavians" and "Scandinavia," particularly prominent from the late 1830s, had at least two sources. Two different notions of "Scandinavia" and "Scandinavians" were put forward during the first decades of the century, from Swedish and Danish agents respectively, characterized by a seemingly similar rhetoric. As a consequence, the significance of being "Scandinavian" changed remarkably. The transformation was part of the rhetorical struggle of what was to be understood more precisely as "Scandinavian" and "Scandinavia."

The following sections will concentrate on these two projects - a Swedishinitiated state-building program from above and a Danish-driven pan-national, nation-building project from below - and their rhetorical uses of the concepts in question. The Norwegian nation-building project, in the making since around 1814 was conversely directed towards Danish cultural and Swedish political dominance, while stressing the principle of reciprocity.

\section{The Swedish Scandinavian Rhetoric}

A second main point regarding the history of "Scandinavian" as a contested concept in the nineteenth century is the significant shift in the use of the term, especially in Swedish newspapers, in 1814. The early Swedish rhetoric of Scandinavianness exploded in 1814, reflecting the establishment of the SwedishNorwegian union that year. ${ }^{15}$ This rhetoric continued into the 1820 s and 1830 s.

13 Den Constitutionelle, 19 February 1837 (editorial article on the front page).

14 "Hartkorn. III," Morgenbladet, 24 November 1839.

15 In Swedish newspapers, there are only 3 examples of the use of "Scandinavian" during the period 1811-1813, but 62 examples in 1814. I have used the word search facilities using the key word followed by an asterisk, to ensure the inclusion of different variants ("skandinavisk ${ }^{\star}$ "/ "scandinavisk ${ }^{\star}$ " and "nordisk ${ }^{\star}$ "). The search is case-insensitive. Svenska dagstidningar, accessed 13 September 2020, tidningar.kb.se. 
Frequently used phrases were, in particular, the "Scandinavian Peninsula" and the "Scandinavian realms" alongside "Scandinavian peoples" and "Scandinavian nations." The recurrent use of the term "Scandinavian" mirrored a discourse and a print culture reflecting the union, one way or another, as part of a growing Swedish public sphere.The term did not, however, refer to the wider Scandinavian region. ${ }^{16}$

The French Marshal Jean Bernadotte, who became Crown Prince Charles John in Sweden in 1810, was pivotal in introducing "Scandinavia" and "Scandinavian" as rhetorical and geo-political terms after $1812 .{ }^{17}$ He made the older imperial Swedish vision of uniting Norway with Sweden his own primary goal. Based on the Treaty of 1812 with Russia, the policy of turning the Scandinavian Peninsula into a Swedish Scandinavian empire was a means to consolidate Sweden after the loss of Finland in 1809.

In Charles John's view and in his rhetoric, "Scandinavia" was therefore delimited to include Sweden and Norway exclusively. This meant to actively forget about Finland and exclude Denmark from the region. Both countries had been included in the definition of "Scandinavia" in Swedish textbooks as late as 1805. ${ }^{18}$ Bernadotte's favourite geopolitical concept was hence that of the "Scandinavian Peninsula," or "what may be termed the Scandinavian Peninsula", as it was framed in one of the key pamphlets distributed throughout Europe, written by August Wilhelm Schlegel in cooperation with Madame de Staël. ${ }^{19}$ The expression suggests that the term was not settled, an impression strengthened by the following Danish reactions, which underlined the neologistic aspect of the con-

16 "Scandinavian," in Sweden at this time referred to the Scandinavian peninsula. An example of this usage is the "Skandinavisk" in Sven Nilsson's Skandinavisk Fauna: En handbok för jägare och zoologer. This publication, among others, contributed to the high prevalence of "Scandinavian" in the Swedish newspapers in 1820s and 1830s. It was first published in 1820 and had three volumes, with additional publications of illustration charts, and was frequently advertised in Swedish newspapers.

17 Ruth Hemstad, Propagandakrig: Kampen om Norge i Norden og Europa 1812-1814 (Oslo: Novus forlag, 2014).

18 Gustaf Abraham Silverstolpe, Lärobok i Svenska Historien (Stockholm: H.A. Nordström, 1805), 12.

19 Mme de Staël, An Appeal to the Nations of Europe against the Continental System (London: J.M. Richardson, 1813), 58. See also Ruth Hemstad, "Madame de Staël and the War of Opinion Regarding the Cession of Norway 1813-1814,” Scandinavica 54, no. 1 (2015): 100 -120. 
cept: "what may be termed (according to Madame de Stäel Holstein's new Geographical Nomenclature) the Scandinavian Peninsula”. ${ }^{20}$

In labelling and naming the new political union of 1814, Swedish authorities utilised both substantivation and adjectivation, introducing the terms "Scandinavia" and "Scandinavians" as common denominators to construct a common identity within the union. Adjectives, it is emphasized, "apply a common denominator to phenomena whose diversity is recognized; substantival labelling, on the contrary, tends to do away with these differences."21 The Swedish "Scandinavia" was an alternative name for Sweden and Norway. "Scandinavians" were accordingly the inhabitants of "Scandinavia," i.e., Swedes and Norwegians. These terms were widely used in books, pamphlets, poems, in newspapers and journals, in geographical textbooks, statistics, encyclopaedias and maps, in official proclamations and published speeches in Sweden. ${ }^{22}$ In one elementary textbook in geography from 1815, "Scandinavia" was even more narrowly defined, as "Sweden in a broad meaning” - meaning "Sweden proper” and Norway, as Daniel Djurberg writes in Geographie för Begynnare. ${ }^{23}$ Norwegians later reacted against this book and its "false" concepts. ${ }^{24}$ However, Djurberg's textbook was commonly used in Swedish elementary schools. This narrow definition was sometimes commented on in Swedish publications, acknowledging that "Scandinavia" usually denotes the three Nordic realms - Sweden, Denmark, and Norway - to provide balance to Swedish authors who had limited the meaning of the term to include only Sweden and Norway. ${ }^{25}$

20 Andreas Andersen Feldborg, Cursory Remarks on the meditated Attack on Norway; Comprising Strictures on Madame de Staël Holstein 'Appeal to the Nations of Europe' (London: Hamblin \& Seyfang, 1813), 82.

21 Marnix Beyen, "Who is the Nation and What Does It Do? The Discursive Construction of the Nation in Belgian and Dutch National Histories of the Romantic Period," in The Historical Imagination in Nineteenth-Century Britain and the Low Countries, ed. Hugh Dunthorne and Michael Wintle (Leiden: Brill, 2013), 69, 76. See also Ruth Hemstad, "The United Kingdoms of Norway and Sweden and the United Kingdom of the Netherlands 1814-1830: Comparative Perspectives on Politics of Amalgamation and Nation Building," Scandinavica 58, no. 2 ([2019] 2020): 76-97. 22 Ruth Hemstad, "Geopolitikk og geografibøker for folket: Den norsk-svenske unionens besværlige beskrivelser,” in Sann opplysning? Naturvitenskap i nordisk folkeopplysning 1650-2016, ed. Merethe Roos and Johan Tønnesson (Oslo: Cappelen Damm, 2017), 101-126.

23 Daniel Djurberg, Geographie för Begynnare, 6th edition (Örebro: N.M. Lindhs förlag, 1815). 24 Carl B. Roosen, Alvorstale i Anledning den i Sverig udgivne Bog: Geographie eör [sic] Begynnare, författad af Daniel Djurberg (Fredrikshald: H. Gundersen \& H. Larsen, 1833).

25 Hemstad, "Geopolitikk og geografibøker for folket." 
In Norway, being forced into this new union with Sweden after leaving the dual monarchy with Denmark after 400 years, there was, as has already been shown, a resistance among parts of the population to these definitions of "Scandinavia," and "Scandinavians." They were interpreted as Swedish rhetorical devices used in order to strengthen the common union, potentially threatening the traditional terms "Norway" and "Norwegians". There was, it may be argued, an enduring awareness against what could be suspected of being Scandinavian imperialistic plans - under disguise of the rhetoric of Scandinavianness - be it from the side of Sweden or Denmark.

Between 1814 and the early 1840s "Scandinavia" was, in Sweden - not in Norway or Denmark - usually used in a narrow sense, equivalent to the term the "Scandinavian Peninsula." The Danish author Christian Molbech also notes in his travel book after a visit to Sweden that this was the common usage in Sweden until around $1840 .^{26}$ By 1848, however, "Scandinavia" was still defined in a Swedish encyclopaedia as an old name for Sweden and Norway, as an originally Latin, historic-poetic denomination of these two countries. ${ }^{27}$ "Scandinavia" was never the name of a political entity, it is underlined. The existing union between Norway and Sweden is, quite strikingly, not mentioned in this entry.

There was a significant increase in the frequency of the term in Swedish newspapers - following a common Nordic pattern - in the 1840s, when the concept is broadened considerably.

\section{The Danish Scandinavian Rhetoric}

In Denmark, as in Sweden and Norway, "Scandinavian” was used to an increasing degree from the beginning of the nineteenth century, along with the traditional and more widespread use of "Nordic." However, "Scandinavia" and "Scandinavian" had a broader meaning in Denmark and Norway compared to Sweden after 1814. As a result of a new orientation towards the neighbouring Scandinavian countries and their common ancient cultural heritage, from the late eighteenth century onwards, journals, books, pamphlets and poems, associations, meetings, and events were using "Scandinavian" as part of their name or title and gradually "Scandinavian" became a widespread adjective. The revival of

26 Christian Molbech, Lund, Upsala og Stockholm i Sommeren 1842: Nogle Blade af en Dagbog med et Tillæg om "den skandinaviske Eenhed" (Copenhagen: Gyldendalske Boghandling, 1844), 283-320.

27 Svenskt konversationslexikon, 3rd ed. (Stockholm: Gustaf Berg, 1848), 547-548. 
interest in Old Norse literature, manuscripts, and monuments contributed to illuminating an ancient common "Nordic" history and culture and at the same time stimulating national consciousness in Denmark, Norway, Sweden - and Iceland. While "Nordic" was the traditional, and usually preferred, term to describe Old Norse culture, indicating a backward-looking cultural orientation, "Scandinavian" more explicitly included Sweden and Norway and had, at least from the 1830 s and 1840s, stronger political connotations. It represented a distinct orientation northward as a way of securing the ancient heritage from German appropriation of the Old Norse legacy. ${ }^{28}$

An early example of a Danish rhetoric of Nordicness was the dissemination of semi-official pamphlets in southern Sweden from 1808 to 1810, propagating the candidacy of the Danish King as King of Sweden. In these pamphlets, the preferred term was "Nordic" rather than "Scandinavian," even if both terms were frequently used. ${ }^{29}$ The choice of Bernadotte as Swedish Crown Prince in 1810 changed the condition for dynastic pan-Scandinavian activities, at least until the 1850 s. $^{30}$

During the 1830s, "Scandinavian" gradually accrued connotations of "newness," and "new ideas," and "Scandinavia" was transformed into the land of the future - a common future for Danes, Swedes, and Norwegians. Old Norse enthusiasm merged with liberal and national reactions to absolute rule and a developing Danish-German conflict over the Duchies Schleswig and Holstein in the divided borderland. The Danish rhetoric of Scandinavianness from the mid-1830s was thus a new kind, in opposition to the authorities and not directed by them. Furthermore, it was influenced by, while at the same time being opposed to, the German national movement at the time. A transnational pan-Scandinavian movement was in the making from the late 1830s, gaining support from liberal-oriented groups and individuals, including publicists, writers, and students, mainly in Denmark and Sweden, during the 1840s.

28 See also Tim van Gerven on the use of this legacy in national consciousness-raising projects: "Scandinavism: Overlapping and Competing Identities in the Nordic World 1770-1919" (PhD diss., University of Amsterdam, 2020, forthcoming Brill, 2022).

29 Ruth Hemstad, "Fra 'det förenade Scandinavien' til 'Nordens Tvillingrige': Skandinavistisk propaganda før skandinavismen, 1808-1814,” in Skandinavism: En rörelse och en idé under 1800-talet, ed. Magdalena Hillström and Hanne Sanders (Göteborg: Makadam förlag, 2014), $56-58$.

30 Morten Nordhagen Ottosen, "Den dynastiske skandinavismens grobunn og grenser, ca. 1845-1870,” in Skandinavismen, ed. Ruth Hemstad, Jes Fabricius Møller and Dag Thorkildsen (Odense: Syddansk Universitetsforlag, 2018), 257-286. 
The pan-Scandinavian movement developed from regional Danish and Swedish collaboration across the Öresund Sound from around 1800, to gradually more institutionalized collaboration between devoted groups in Denmark, Sweden and, more hesitantly, Norway and Finland. The movement sought to construct a common Scandinavian identity by highlighting the common Old Norse heritage, the kindred languages, and cultural similarities among "Scandinavians." In addition, it focused on the strategic political need to stand up to Prussia and Russia. ${ }^{31}$ The movement gained momentum and spread from Denmark to the other Scandinavian countries foremost through the spectacular social and political student events taking place from the early 1840s, the so-called "Scandinavian student voyages," which were media events at the time..$^{32}$ Influenced by these impulses, to be a "Scandinavian" in Swedish rhetoric gradually also included the Danes.

Meetings, associations, and events led to new and strengthened transnational networks. Through a comprehensive and conscious use of journals, newspapers, pamphlets, books of different kinds, songs, poems, and speeches, a new pan-Scandinavian vocabulary was widely spread and circulated to the Nordic countries and beyond. ${ }^{33}$ The effect this had in increasing the frequency of the term "Scandinavian" in the newspapers, not only in Denmark but in all the Nordic countries, is striking.

In 1843, after a student meeting in Uppsala, the publicist and scholar Ludvig Kristensen Daa, one of the few Norwegians publicly and positively oriented towards the new "Scandinavian ideas," wrote in his journal Granskeren about the current movement: "Lately, the youth of our neighbours and brothers, the Swedish and Danish youngsters, have also [as among the Italian and German youth] found their great idea, namely the Scandinavian idea of Nordic

31 Åke Holmberg, Skandinavismen i Sverige vid 1800-talets mitt (Göteborg: Elanders boktrykkeri, 1946); Erik Møller, Skandinavisk stræben og svensk politik omkring 1860 (Copenhagen: Gad, 1948); Henrik Becker-Christensen, Skandinaviske drømme og politiske realiteter: Den politiske skandinavisme i Danmark 1830 - 1850 (Aarhus: Arusia, 1981); Rasmus Glenthøj, 1864: Sønner av de slagne (Copenhagen: Gad, 2014), Rasmus Glenthøj and Morten Nordhagen Ottosen, Union eller undergang. Kampen for et forenet Skandinavien (Copenhagen: Gads Forlag, 2021).

32 Jonas Harvard and Magdalena Hillström, "Media Scandinavianism: Media Events and the Historical Legacy of Pan-Scandinavianism," in Communicating the North: Media Structures and Images in the Making of the Nordic Region, ed. Peter Stadius and Jonas Harvard (Farnham: Ashgate Publishing, 2013), 75-98.

33 Ruth Hemstad, “'En skandinavisk Nationalitet’ som litterært prosjekt: 1840-årenes transnasjonale offentlighet i Norden," in Nation som kvalitet: 1800-talets litterära offentligheter och folk $i$ Norden, ed. Anna Bohlin and Elin Stengrundet (Bergen: Alvheim \& Eide akademisk forlag, 2021). 
unity." ${ }^{34}$ The Norwegian youth were, however, more hesitant. The discussions in the Norwegian Student association after this meeting were predominantly critical of the new ideas. ${ }^{35}$

The "Scandinavian idea of Nordic unity" was only one out of a great many similar phrases and frequently used expressions that were consciously employed by pan-Scandinavian activists. These phrases may be seen as part of a renewed Scandinavian political language, disseminated in different ways, that was used as a means to achieve political goals. ${ }^{36}$ Based on the reformulated, rhetorical concept of a "Scandinavian" as someone supportive of the "Scandinavian idea" and the broader understanding of "Scandinavia" - being the land of the common prosperous future - the concept of "Scandinavianism" emerged. This new ism, which mirrored other pan-national movements of the day, was commonly in use after $1844 .^{37}$

In 1839, Fredrik Barfod's quarterly journal Brage og Idun, the first transnational journal with an explicit pan-Scandinavian agenda, was published and circulated to Scandinavian, mainly Danish and Swedish, subscribers. The term "Scandinavian" was regularly used in the five volumes published between 1839 and 1842, when Barfod's enterprise was stopped due to censorship restrictions. Examples are phrases like "a Scandinavian soul”, "Scandinavian endeavours", "Scandinavian nations", "Scandinavian sympathies", a "Scandinavian mindset" and "the Scandinavian North". The dominance of the term "Nordic" in the journal however outnumbers that of "Scandinavian" by a wide margin. ${ }^{38}$

Significant is also the first "Scandinavian Meeting of Natural Scientists" held in Gothenburg in 1839. Inspired by German, British, and Swiss examples, it was the first in a range of regularly held transnational meetings within different professions and groups across the Nordic region. Advocates of the "Scandinavian idea," attending the meeting in 1839, claimed that it was the first proof of "a scientific union of the North." 39 It was interpreted as a sign of Scandinavian recon-

34 “Om Skandinavien,” Granskeren, 15 June 1843.

35 See also Frederik Wallem, Det norske Studentersamfund gjennom hundrede aar: 1813-1913, vol. 1 (Kristiania: Aschehoug, 1916), 272-281; John Sannes, Patrioter, intelligens og skandinaver: Norske reaksjoner på skandinavismen før 1848 (Oslo: Universitetsforlaget, 1959).

36 For more on the languages of politics - including their role in shaping citizens' actions and constituting their worldviews, see David Craig and James Thomson, eds., Languages of Politics in Nineteenth-Century Britain (London: Palgrave Macmillan, 2013), 1-20.

37 Ruth Hemstad, "Scandinavianism: Mapping the Rise of a New Concept," Contributions to the History of Concepts 13, no. 1 (2018): 1-21.

38 In the five published and digitized volumes there are 36 mentions of "Scandinavian" and 300 of "Nordic" (table of contents and register not included).

39 See Hemstad, Fra Indian summer, 49. 
ciliation and the necessity of closer collaboration. Numerous speeches during the meeting - published in Scandinavian newspapers and journals such as Brage og Idun, and as part of the published account of the meeting - demonstrated an eager use of the rhetoric of Scandinavianness. Several similar meetings and related associations termed themselves "Scandinavian" from the 1840s onwards. ${ }^{40}$

After the first grand student meeting in Uppsala in June 1843, associations with a pan-Scandinavian goal were established in Copenhagen and Uppsala. The aim was to strengthen the cultural connections between the three Scandinavian countries. In Denmark, the new Skandinavisk Samfund [Scandinavian society], established by students and leaders of the pan-Scandinavian movement, was prohibited by the authorities, due in part to its name. The prohibition caused a sharp debate in the public sphere and probably only helped to strengthen the movement. The Copenhagen cultural elite soon established another association, Skandinavisk Selskab, in September 1843. This time, the association got the necessary approval on the explicit precondition that their meetings would not be used for political discussion. A similar association, Skandinaviska Sällskapet, was established in Uppsala in October 1843.

The pan-Scandinavian profile of these new associations is emphasized in a Swedish encyclopaedia published 1848, in a separate entry on "Scandinavian association."

Scandinavian societies is the name of the associations, which in recent years have been established within as well as outside Scandinavia, in order to contribute to the development of the common Swedish, Norwegian and Danish nationality. The purpose of these associations is to stimulate the feeling of one nationality, not Swedish, Norwegian or Danish, but Scandinavian..$^{41}$

The encyclopaedic definition is illuminating regarding the use of the term "Scandinavian," and phrases like "the Scandinavian idea” and "the Scandinavian nationality," and the perceived role of "Scandinavian associations" in this pan-national project. "Scandinavian" associations abroad were part of this picture. PanScandinavian diaspora associations abroad, by and for Scandinavians working in or travelling to other parts of the world, were usually open to all "Scandinavians" in a certain city and commonly termed themselves a "Scandinavian association.” They were established in a range of European cities from the 1840s on-

40 A list of meetings held in the Nordic region from 1839 to 1929 is included as an appendix in Hemstad, Fra Indian summer.

41 Translation by the author. Svenskt konversationslexikon 3: 547-548. 
wards, and among emigrants in the United States, Australia, and Africa. ${ }^{42}$ Several of the new associations abroad stayed in contact with the Scandinavian associations back home, which helped to build up "Scandinavian libraries" abroad by sending "Scandinavian literature," including books, journals, and newspapers. News from these diaspora associations were reported on regularly in newspapers in Denmark, Norway, and Sweden, contributing to a transnational discourse.

An interesting, revealing discussion suggesting that "Scandinavian" was assumed as a potentially more political term than "Nordic" in the 1840 s took place in Hamburg when a cultural-literary association was established in late 1842 by Scandinavians - predominantly Danes - as the first of its kind in the nineteenth century. The discussions reached the Scandinavian newspapers, which reported that the Swedish-Norwegian and Danish diplomatic representatives in Hamburg were informed about the new association, which had termed itself a "Scandinavian association." 43 This was not a problem for the Swedish diplomats. The Danish envoy, however, protested, fearing potential political reactions to the use of the term "Scandinavian," including, in particular, the potential reaction of the Russian court. As a result, the association chose the apparently more neutral term "Nordic," calling itself Nordisk Læseforening [the Nordic reading society]. The following spring, however, the original name was restored. The "Scandinavian association" in Hamburg continued until 1912 and was regularly reported on in the Scandinavian press as an example of Scandinavian sentiments and cooperation abroad. This picture changed totally, however, due to the dissolution of the Norwegian-Swedish union in 1905, causing a renewed quarrel regarding the naming of the association after the Swedish members demonstratively left the association.

\section{The Scandinavian Vocabulary Turn}

A third point in the history of the rhetoric of Scandinavianness is the sharp rise in the frequency of the term "Scandinavian" from the mid-1840s. This applies to

42 Ruth Hemstad, "Organizational Scandinavianism Abroad”; Ruth Hemstad, "Literature as Auxiliary Forces: Scandinavianism, Pan-Scandinavian Associations and Transnational Dissemination of Literature," in Culture and Conflict: Nation-building in Denmark and Scandinavia 1800 1930, ed. Sine Krogh, Thor Mednick and Karina Lykke Grand (Aarhus: Aarhus University Press, 2022), 161-164.

43 Originally referred to in Aalborg Stiftstidende og Adresse-Avis, 27 January 1843. On the association in Hamburg, see also Hemstad, "Organizational Scandinavianism Abroad." 
newspapers in Denmark, Sweden, and Norway - and to a certain degree in Finland - indicating the emergence of what could resemble a Nordic public sphere. There are different limitations regarding the scope and quality of the digitized material in the various Nordic newspaper corpora, especially when it comes to older printed publications, and there is still a lack of digitized journals and other printed material. The newspaper databases give, however, a clear indication of the changes in the vocabulary and of the frequencies of terms such as "Scandinavian" and "Nordic."44

In Danish newspapers, there was a gradual rise in the use of the term "Scandinavian" since 1800, but this changed dramatically in the 1840 s. From a relatively low frequency during the 1830s the frequency increased by a factor of twenty in the 1840s. ${ }^{45}$ Almost a quarter of these mentions originates from the pro-Scandinavian newspaper Fædrelandet. ${ }^{46}$ This is almost as many occurrences as the overall more frequent term "Nordic" in Danish newspapers during this decade. ${ }^{47}$ After a gradual rise in the 1850 s, there was another sharp rise in the use of "Scandinavian" in the 1860 s. $^{48}$ From the 1870 s, the gradual rise of "Scandinavian" continued, while "Nordic" again became clearly more dominant (fig. 1).

This development corresponds partly - and especially for the period between the 1830s and the 1860s - with the Swedish, Norwegian, and Finnish results. The comparison also reveals an interesting difference between a dominant frequency of "Nordic" in Denmark and Finland, and a relatively more frequent use of "Scandinavian" in Sweden and Norway for the period between the 1870 s and the 1890s. In Swedish newspapers, "Scandinavian" rises markedly from the 1830 s to the 1840 s, even surpassing the frequency of the term "Nor-

44 This is valid also when the frequency is measured in absolute numbers of hits/mentions (the number of hits in the newspaper databases reflects the amount of newspaper issues with mentions of "Scandinavian" or "Nordic", not the total amount of mentions in each issue put together). For the Norwegian material, relative frequency supports the findings in this study.

45 The frequency of the term "Scandinavian" in Danish newspapers rose from 161 mentions during the 1830 s to 3,795 mentions during the 1840s. (An asterisk ["skandinavisk ${ }^{\star}$ "] was added to the keyword search to ensure the inclusion of different variants. The search is case-insensitive.) Mediestream, accessed 13 September, 2020, www2.statsbiblioteket.dk/mediestream.

46 There were 885 mentions of "Scandinavian" in Fædrelandet during the 1840s.

47 The frequency of the term "Nordic" ("nordisk") rose from 2,046 mentions during the 1830s to 4,038 mentions during the 1840 s.

48 There are 13,253 mentions of "Scandinavian" during the 1860s compared to 18,807 mentions of "Nordic" during the same period. 
Figure 1: Frequency of the terms "Scandinavian" and "Nordic" in Danish newspapers $1810-$ 1899.

Source: Mediestream, accessed 13 September, 2020, www2.statsbiblioteket.dk/mediestream. Illustration copyright Lars G. Johnsen, National Library of Norway.

dic." ${ }^{49}$ After a gradual rise in the 1850s, the use of "Scandinavian" again rose considerably in the $1860 \mathrm{~s}^{50}$ In the 1870 s, there was a gradual rise of both terms, with "Nordic" only again slightly surpassing "Scandinavian" in the decade between 1890 and 1899 (fig. 2).

Figure 2: Frequency of the terms "Scandinavian" and "Nordic" in Swedish newspapers 1810 1899. Source: Svenska dagstidningar, accessed 13 September 2020, tidningar.kb.se. Illustration copyright Lars G. Johnsen, National Library of Norway.

49 The frequency of the term "Scandinavian" ("skandinavisk") in Swedish newspapers rose from 710 mentions during the 1830 s to 5,967 mentions during the 1840 s. The frequency of the term "Nordic" ("nordisk") rose from 1,718 mentions during the 1830s to 5,551 during the 1840s. (A search on "scandinavisk" gave 32 additional hits during the 1830s, and 83 hits during the 1840s. The search is case-insensitive). Svenska dagstidningar, accessed 13 September 2020, www.tidningar.kb.se.

50 There are 25,688 mentions of "Scandinavian" during the 1860s compared to 19,524 of "Nordic" during the same period. Included in this result are also advertisements for the bank Skandinaviska Kreditaktiebolaget, founded in 1864. 
In the Norwegian digitized newspaper corpus, the same tendency is prevalent, even if the contemporary number of newspapers was considerably less in Norway than in the established Danish and Swedish print cultures. "Scandinavian" was used moderately in the 1830s before its usage rose significantly in the 1840 s (cf. fig. 3). ${ }^{51}$ In the same period, the term "Nordic" also rose, but comparatively less. ${ }^{52}$ The 1850 s represented a relative rise in the frequency of "Scandinavian", surpassing that of "Nordic." From the 1870s to the 1880, "Nordic" was slightly more widespread. During the 1890s, "Scandinavian" again surpassed "Nordic," but since 1900, "Nordic" has gradually become the most dominant term again.

- Norwogian newspapers skandinavisk"
Noweqlan newspapers nordisk.

Figure 3: Frequency of the terms "Scandinavian" and "Nordic" in Norwegian newspapers 1810-1899. Source: National Library of Norway, accessed 13 September 2020, www.nb.no. IIlustration copyright Lars G. Johnsen, National Library of Norway.

Swedish language newspapers in Finland also reflect the same development. The newspaper corpus displays an increase in the term "Scandinavian" from the 1830 s to the 1840 s compared to that of "Nordic". ${ }^{53}$ There is a gradual increase of both terms in the 1850 s and 1860s with a clear increase of "Nordic" in the 1870 s and of both terms in the 1880 s followed by a minor decrease of "Scandinavian" in the 1890s. The term "Nordic" is overall more frequent in this corpus during the whole period from 1810 to 1900 (fig. 4).

51 The frequency of the term "Scandinavian" ("skandinavisk") in Norwegian newspapers rose from 79 mentions during the 1830 s to 1,209 mentions during the 1840 s. (The search is case-insensitive). National Library of Norway, accessed 13 September 2020, www.nb.no.

52 The frequency of the term "Nordic" ("nordisk") rose from 486 mentions during the 1830s to 1,954 mentions during the 1840 s.

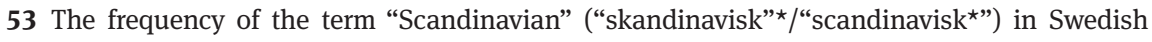
language newspapers - and advertisements in Swedish in Finnish language newspapers - in Finland rose from 95 mentions during the 1830s to 227 mentions during the 1840 s. The frequency of the term "Nordic" ("nordisk") rose from 218 mentions during the 1830s to 457 mentions during the 1840s. (The search is case-insensitive). DIGI, accessed 16 September 2020, digi.kansalliskirjasto.fi. 
Figure 4: Frequency of the terms "Scandinavian" and "Nordic" in Swedish-language newspapers in Finland 1810-1899. Source: DIGI, accessed 16 September 2020, digi.kansalliskirjasto.fi. Illustration copyright Lars G. Johnsen, National Library of Norway.

The references to "Scandinavian" and "Nordic" in Nordic newspapers in general covers editorial content, as articles and submitted letters, but also advertisements, announcements, and lists of publications, reflecting the widespread use of these terms in different contexts. During the nineteenth century "Scandinavian" and "Nordic" were increasingly used in names of journals, newspapers, firms, organizations, cultural institutions, and different enterprises of a transnational character. This tendency reflects a general transnational development and indicates that a Scandinavian/Nordic orientation had become an integrated, "ambient" part of cultural and social life across the region and could also be utilised for branding purposes. ${ }^{54}$ Part of this picture is the rising number of meetings and associations using "Scandinavian" or "Nordic" in their names. ${ }^{55}$

\section{Scandinavian Sympathies and Related Phrases}

The sharp rise in the frequency of the term "Scandinavian" in Nordic newspaper corpora also reflects the range of new phrases entering the new pan-Scandinavian vocabulary. Illustrative is the critical discussion by Christian Molbech in his travel account published in 1844 where he added an almost forty-page long, highly critical appendix regarding what he called "the Scandinavian

54 Tim van Gerven uses the phrase "ambient Scandinavism” to describe how markers of a panScandinavian identity (such as literature, monuments, and street-names) became an unobtrusive background of daily life during the late nineteenth century. Van Gerven, "Scandinavism," 264, 327.

55 See appendix in Hemstad, Fra Indian summer. 
idea" or "the Scandinavian idea of unity." 56 The text demonstrates how the term "Scandinavian" was used in an already flourishing amount of new expressions and phrases, among them a "new Scandinavianness," a "Scandinavian connection," the "Scandinavian North," the "new Scandinavia," "the first sudden Scandinavian enthusiasm," "Scandinavian sympathies," and "the Scandinavian issue."

In Sweden, the term "Scandinavian" was redefined in the 1840s, even if, as we have seen, the previous narrower use and understanding continued alongside the new interpretation. Newspapers and journals naming themselves "Scandinavian" in the 1840s hence referred explicitly to another, larger, and future-oriented "Scandinavia" than what had hitherto been the case. ${ }^{57}$

Along with the marked increase in the term "Scandinavian," there was a renewed interest in "Nordic" as part of the new political-cultural vocabulary. A key phrase here is Nordens Eenhed [Nordic unity/unity of the North], sometimes specified as a spiritual, cultural, or even political, unity.

Some specific phrases are used throughout the century, with periods of increasing and decreasing usage. Other phrases, interestingly, only turn up during limited time periods. Some of these word combinations are seemingly quite neutral, while others are ambiguous, charged with meaning and clearly rhetorical. It is possible to identify and analyse through a combination of close and distant readings phrases of interest, frequently used expressions, and term co-occurrences. By counting the frequencies of certain bigrams in the text corpus at the National Library of Norway and searching for key words and specific phrases in Nordic newspaper databases, as well as conducting close readings of relevant material, one can begin to see several patterns appear. ${ }^{58}$

Several of the new phrases found in this research were coined by pan-Scandinavian activists. Some of the phrases with the term "Nordic" are integrated

56 Christian Molbech, "Om 'den skandinaviske Eenhed," in Molbech, Lund, Upsala og Stockholm, 28. Molbech's list also demonstrates a contemporary use of the term "Scandinavianness," see page 297. See also Hemstad, "Scandinavianism," 11.

57 “Anmälan,” Tidning för Skandinavien, 30 December 1843.

58 Bigram collocations based on newspaper and books, 1790-1920 are made available for this study by Lars G. Johnsen. N-gram resources at the National Library of Norway: https:// www.nb.no/sprakbanken/ressurskatalog/oai-nb-no-sbr-35/. For descriptions of data resources at NBdigital, see Magnus Breder Birkenes et al., "From Digital Library to N-Grams: NB Ngram," in Proceedings of the 20th Nordic Conference of Computational Linguistics (Linköping, 2015), 293-295. See also Lars Johnsen, "Eldre bøker i den digitale samlingen: Et elektronisk blikk på tekster fra perioden 1650-1850," in Litterære verdensborgere: Transnasjonale perspektiver på norsk bokhistorie 1519-1850, ed. Aasta Marie Bjorvand Bjørkøy et al. (Oslo: National Library of Norway, 2019), $190-214$. 
parts of the pan-Scandinavian rhetoric, having clear political implications and connotations, such as "Nordic unity," "Nordic spirit/volksgeist," and "Nordic union/federation/alliance." More frequent in the rhetoric applied by the panScandinavian movement, and used mainly from the 1840s until the 1860s, were phrases such as "Scandinavian sympathies"; the "Scandinavian idea" or the "Scandinavian idea of unity"; the "Scandinavian issue/question"; the "Scandinavian union"; and "Scandinavian efforts/endeavours." Other frequent phrases are the "Scandinavian people(s)," "Scandinavian nation(s)/nationality," and "Scandinavian aims/purposes." Widespread are also phrases including "Norden" or "Scandinavia," as the "Scandinavian North," the "spiritual unity of the North," "Our Norden/Scandinavia," and "the unity of Norden/Scandinavia." Even "Scandinavian associations," as we have seen, could be understood as a specific form of association, meant to propagate "Scandinavian ideas" and promote the knowledge of "Scandinavian literature." Many of these phrases were used in all three Scandinavian countries, as a transnational pan-Scandinavian vocabulary with shared key concepts, others were mainly used in one or two countries, like the "Scandinavian fatherland," which was mostly a Danish invention. All these phrases should be seen as part of the discursive, semantic context surrounding the pan-Scandinavian movement.

"Nordic" and "Scandinavian" were to a certain extent interchangeable concepts during most of the nineteenth century, which the bigram counts also support. In many instances, and out of esthetical-poetical reasons, there was a question of using alternatives in the descriptions used. The term "Nordic" is overall clearly more dominant during the whole century, but "Scandinavian" increased to a certain point in Denmark in the 1860s and early 1870s, and in Norway and Sweden until the 1890s, followed by a relative decline. Some phrases were usually, or only, used in combination with either "Nordic" or "Scandinavian." Typically, descriptive phrases of the area and territory used these terms interchangeably, for example: "Scandinavian/Nordic countries," "Scandinavian/Nordic Kingdoms/realms," and "Scandinavian/Nordic states" - an exception to this tendency is the description of the peninsula, "Scandinavian Peninsula" predominates with only a few, mainly Norwegian, examples of the phrase "Nordic Peninsula." Phrases that refer to the inhabitants of territory follow the same logic: "Scandinavian/Nordic peoples" and "Scandinavian/Nordic nationalities/nations". Some of these terms could also be used in singular, rhetorically underlining the unity among the Scandinavians, such as "the Scandinavian people/nationality/nation". Some phrases changed gradually from "Scandinavian" to "Nordic" during the century, such as "Scandinavian/Nordic cooperation," and related to this, "Scandinavian/Nordic meetings/associations". 
Some phrases could change their meaning, depending on the context, as part of a Swedish or a Danish rhetoric. The "Scandinavian union" could mean Sweden and Norway or Denmark, Sweden, and Norway, and the inhabitants in question - the "Scandinavians" - could mean the Swedish and Norwegian people or the Danish, Swedish, and Norwegian people or even, more explicitly, the Danish, Swedish and Norwegian supporters of the "Scandinavian idea." A "Scandinavian song" could be praising the union between Sweden and Norway, especially when written around 1814 or it could, later on, be one of the hundreds of songs distributed during the "Scandinavian/Nordic student meetings."

Some phrases are predominantly "Nordic," like the ones describing Old Norse heritage..$^{59}$ Old Norse history, language, and antiquities were dominantly termed "Nordic," not "Scandinavian." In the Sagas themselves, "Scandinavian" was not used, as was emphasized in the Norwegian critique against Danish attempts to claim part of the ownership to this heritage. "Nordic" was preferred as well when speaking of Vikings, pagans, Gods and runes, as well as tribes. History was also dominantly "Nordic." There are "Nordic mythology/legends," as well as "Nordic folk songs/fairy-tales/poetry/art/authors," but "literature" could either be described as "Scandinavian" or "Nordic." And although countries, states, and realms are interchangeably "Nordic" or "Scandinavian," there are seemingly only "Nordic powers" and a "Nordic force."

The rhetoric of Scandinavianness around 1840 was soon met by counter concepts clearly indicating the ambiguity embedded in these concepts. One of these, although quite rare, was "Unscandinavian." Another, more frequently used, was "antiscandinavian.” There were also "antiscandinavians," referring negatively to "Scandinavians," or "so-called Scandinavians," referring to someone who was in favour of the "Scandinavian idea." "Unscandinavian" was used in an article in the Danish satirical and political magazine, Corsaren, while mocking the incredible number of speeches and toasts being held at the huge "Nordic" student meeting in Copenhagen during the summer of 1845. The author claims there were "247 Scandinavian speeches... always about one and the same thing, that Denmark, Norway and Sweden had been in disagreement, but now were the best of friends - that is simply too much... that is unscandinavian." 60

59 See also J.J.A. Worsaae, “Om vigtigheden af et centrum for Nordisk Oldforskning," Annaler for Nordisk Oldkyndighed og Historie, 1846: 3-20. In Sweden, "Scandinavian” was also used to describe this past history. "Nordic race" is, however, seemingly not commonly used (on humans) until the 1920s. See also Merle Weßel in this volume.

60 Corsaren, 4 July 1845, cited after Julius Clausen, Skandinavismen historisk fremstillet (Copenhagen: Det Nordiske Forlag, 1900), 101. Corsaren was edited by M.A. Goldschmidt. 
The development in the rhetorical use of "Scandinavian" in the 1840s cannot be understood without considering the impact of the pan-Scandinavian movement. The usage culminated with the two German-Danish wars on the Duchy of Schleswig, 1848-51 and 1864, resulting in the Danish loss of Schleswig. During the 1870s, the 1880s, and most of the 1890s the rhetoric of Scandinavianness was less outspoken, but still not completely forgotten.

\section{From the Rhetoric of Scandinavianness to the Rhetoric of Nordicness}

A fourth point regarding the rhetoric of Scandinavianness in the nineteenth century is the renewed interest at the turn of the century followed by a rejection of these concepts in conservative parts of the Swedish public sphere. This development probably contributed to strengthening another tendency, which is the final main point, namely, that the rhetoric of Scandinavianness gradually transformed into a rhetoric of Nordicness from the last part of the nineteenth century onwards. This last section will briefly look into this development.

The period of specific interest is around the year 1900, which saw a revival of pan-Scandinavian sentiments stimulated by what was termed "neo-Scandinavianism." 61 A range of "Scandinavian" and "Nordic" associations and meetings filled the air, many of them using a rhetoric reminiscent of earlier periods. This Indian summer period, also reflecting Russian and German pressure against Finland and the Danish borderlands respectively, turned, however, into a cold Nordic winter after the dissolution of the Norwegian-Swedish union in 1905. Swedish "neo-Scandinavianists" openly declared the final death of "Scandinavianism" caused by Norway unilaterally leaving the union. Swedish reactions hence turned against the flourishing Nordic cooperation at the time, including the many Scandinavian associations established abroad, such as the one in Hamburg. The terms "Scandinavia" and "Scandinavian" were no longer appealing but rather contested and were rejected as inappropriate and in conflict with Swedish national interests in conservative parts of the Swedish public sphere. ${ }^{62}$

The pan-Scandinavian associations abroad, usually termed "Scandinavian," not "Nordic," continued to celebrate "Scandinavian" culture, traditions, and spirit, along with "Nordic Christmas" and "Scandinavian friendship” until the dis-

61 Hemstad, Fra Indian summer, 87-229.

62 "De 'skandinaviska' sjömanshemmen utomlands," Göteborgs Aftonblad, 17 July, 1908. 
solution of the union in 1905. In 1906 and 1907, following the dissolution, and the subsequent anti-Scandinavian sentiments in Sweden, many associations, especially in European cities, were terminated. ${ }^{63}$ The Scandinavian Association in Rome, established 1860, was one of the few older associations to survive 1905, and it is still in operation today.

An encyclopaedic entry in the Swedish Nordisk Familjebok - not an untypical name at the time - illuminates the conceptual changes within this field. The entry for "Scandinavian associations abroad" was still included in the 1917 volume, but without any definition, only a reference to another entry: "see Swedes living abroad." 64 Utlandssvenskar was then defined as "Swedish speaking citizens of Swedish origin" (including former Swedish territories), living in a state other than Sweden. ${ }^{65}$ Several of the pan-Scandinavian associations abroad had been dissolved and new, nation-based clubs were established instead, backed by national umbrella organizations in the home countries.

The naming of transnational meetings within Scandinavia illustrates the transformation from "Scandinavian" to "Nordic" during the last part of the nineteenth century. Beginning with the first meeting series, that started in 1839, and in the decades following, associations and meetings across the region were termed "Scandinavian." During the 1860s, new meetings were either called "Scandinavian" or "Nordic." Starting with the 1870s, however, new meetings and conferences were primarily called "Nordic" rather than "Scandinavian," in part reflecting a growing number of Finnish participants. After 1900, there are only rare exceptions still using the adjective "Scandinavian" for these kinds of transnational activities. ${ }^{66}$

The same pattern can be seen in the names of the pan-Scandinavian oriented networks of associations. Within Scandinavia, associations with pan-Scandinavian ambitions, although nationally based, were established in three different, short-lived rows during the nineteenth century. The naming of them changed over time following the main transformation from "Scandinavian" to "Nordic." A forerunner was the above-mentioned Scandinavian Literary Society, established in 1796. During the 1840s, the associations were, as we have seen, termed "Scandinavian." When new associations were established after the second Ger-

63 Hemstad, "Organizational Scandinavianism Abroad"; Hemstad, Fra Indian summer, 345359.

64 "Skandinaviska föreningar i utlandet: Se Utlandssvenskar," Nordisk Familjebok 25, 2nd ed. (Stockholm, 1917), 876.

65 Nordisk Familjebok 31 (Stockholm, 1921), 111.

66 Among the exceptions are "Scandinavian Labour Congresses," "Scandinavian Dentists Meetings," and "Scandinavian Woman Conferences". See appendix in Hemstad, Fra Indian summer. 
man-Danish war in 1864, they were termed "Nordic" in Sweden and Denmark. The first association of this kind in Norway, established during the war, termed itself however "Scandinavian" [Skandinavisk Selskab]. As part of the revival of pan-Scandinavian notions after 1899, new associations were founded, using a common name: Nordisk Forening [Nordic association]. After a period of reduced cooperation and contact after 1905, the First World War reactivated Nordic cooperation, meetings, and transnational associational life. Foreningene Norden [Norden associations] were established not only in the Scandinavian countries in 1919, but also in Iceland in 1922, in Finland in 1924, and later in the Baltic area. They proved to have a longer life than their predecessors did. They have represented, and still represent, an enduring rhetoric of Nordicness.

\section{Conclusion}

This chapter has explored the emergence, rise, and decline of the term "Scandinavian” as a flexible and contested concept in newspapers published in Denmark, Sweden, Norway and Finland in the long nineteenth century. Based on an approach combining close and distant reading, through key word and collocate searching of Nordic newspapers, and additional readings of journals, books, and pamphlets, it argues that the use of the term "Scandinavian," along with a revived use of the older and more common term "Nordic," increased rapidly in the Nordic countries in the 1840s. The study demonstrates how different groups have sought to claim the term "Scandinavian" for their own purposes, leading to rhetorical struggles. A rhetoric of Scandinavianness - utilising the relatively rare and unsettled term "Scandinavian" compared to that of "Nordic" around 1800 was used in competing Swedish and Danish pan-national projects. The use of the term "Scandinavian" exploded within the new Scandinavian public sphere that emerged in the 1840s, with associations, journals, and newspapers promoting the "Scandinavian idea." New connotations were attached to established terms, and a range of conceptual innovations with rhetorical power led to conceptual contests and disputes.

While the Swedish interpretation of "Scandinavia" and "Scandinavian" - as restricted to the Scandinavian Peninsula - used in the decades following 1814 has more or less faded into oblivion, the pan-Scandinavian movement of the mid-nineteenth century, it may be argued, had an enduring influence on the contested rhetoric of Scandinavianness and Nordicness throughout the century - 
and well beyond. ${ }^{67}$ The re-politicization of this concept around $1900-1905$, and the national tensions and anti-Scandinavian sentiments after 1905, contributed to making it even more contested. When the transnational cooperation started up again around 1918, and with Finland and Iceland as integrated parts of it, the term "Nordic" was the most appropriate adjective to use, although it continued to be flexible, appealing, and contested, as the following chapters of this volume demonstrate.

67 Hemstad, Fra Indian summer, 394-418; Hemstad, "Scandinavianism, Nordic Co-operation and 'Nordic Democracy,"” in Rhetorics of Nordic Democracy, ed. Jussi Kurunmäki and Johan Strang (Helsinki: Finnish Literature Society, 2010), 179-193. 
